\title{
Faktor-Faktor yang Berhubungan dengan Kesejahteraan Subjektif Caregiver Orang dengan Skizofrenia di Bantur Malang
}

\section{Factors Related to Schizophrenia Caregivers' Subjective Well-Being in Bantur Malang}

\author{
Yhummei Veronia $F^{1}$, Lilik Zuhriyah', Rinik Eko $K^{3}$ \\ ${ }^{1}$ Program Studi Magister Keperawatan Fakultas Kedokteran Universitas Brawijaya Malang \\ ${ }^{2}$ Departemen IImu Kesehatan Masyarakat Fakultas Kedokteran Universitas Brawijaya Malang \\ ${ }^{3}$ Departemen Keperawatan Fakultas Kedokteran Universitas Brawijaya Malang
}

\begin{abstract}
ABSTRAK
Skizofrenia merupakan gangguan jiwa berat yang memerlukan caregiver. Perawatan orang dengan skizofrenia di rumah dapat menjadi beban bagi caregiver seperti kesulitan dalam menangani perilaku orang dengan skizofrenia, cemas hingga stres. Beban perawatan orang dengan skizofrenia dapat membuat caregiver kurang memiliki waktu untuk istirahat dan kesejahteraan semakin rendah. Penelitian ini dilakukan untuk mengetahui faktor-faktor yang berhubungan dengan kesejahteraan subjektif pada caregiver yang merawat orang dengan skizofrenia di Wilayah Kerja Puskesmas Bantur Kabupaten Malang. Penelitian ini merupakan penelitian observasional dengan pendekatan cross-sectional. Sampel penelitian yaitu caregiver yang merawat orang dengan skizofrenia selama 24 jam. Caregiver yang merawat orang dengan skizofrenia diperoleh dengan purposive sampling sebanyak 102 orang. Analisis data dilakukan dengan uji korelasi Rank Spearman untuk analisis bivariat dan regresi logistik berganda untuk mengetahui faktor yang paling dominan berhubungan dengan kesejahteraan subjektif pada caregiver orang dengan skizofrenia. Hasil analisis bivariat menunjukkan bahwa variabel yang berhubungan positif dan signifikan dengan kesejahteraan subjektif secara berturutturut yaitu hubungan sosial $(r=0,538, \rho=0,000)$, sikap optimis $(r=0,356, \rho=0,000)$, kontrol diri $(r=0,306, \rho=0,002)$ dan harga diri $(r=0,279, \rho=0,005)$. Hasil regresi logistik berganda menunjukkan bahwa hubungan sosial memiliki odds ratio (OR) paling besar yaitu 16,061 artinya hubungan sosial yang baik akan meningkatkan kesejahteraan subjektif 16 kali lebih tinggi dibandingkan dengan caregiver orang dengan skizofrenia yang tidak menjalin hubungan sosial yang baik dengan orang lain. Hubungan sosial merupakan faktor yang paling dominan berhubungan dengan kesejahteraan subjektif pada caregiver orang dengan skizofrenia. Caregiver orang dengan skizofrenia yang menjalin hubungan sosial yang baik dengan orang lain akan mengalami kebahagiaan dan kepuasan hidup sehingga dapat meningkatkan kesejahteraan subjektif.
\end{abstract}

Kata Kunci: Caregiver, skizofrenia, kesejahteraan subjektif

\begin{abstract}
Schizophrenia is a severe mental disorder that requires a caregiver. Treating people with schizophrenia at home can be a burden for the caregiver such as the difficulties in handling the behavior of people with schizophrenia, anxiety, and stress. The burden of caring people with schizophrenia can make the caregiver lack time to rest and lower well-being. This study was conducted to determine the factors related to subjective well-being of caregivers who treat people with schizophrenia in the Working Area of Bantur Health Center, Malang Regency. This study was an observational study with a cross-sectional approach. The research sample was caregiver who treated people with schizophrenia for 24 hours. Caregivers who treat people with schizophrenia were obtained by purposive sampling as many as 102 people. Data analysis was performed by Rank Spearman correlation test for bivariate analysis and multiple logistic regression to determine the most dominant factors related to subjective well-being of caregivers of people with schizophrenia. The results of the bivariate analysis show that the variables that are positively and significantly related to subjective well-being are social relations ( $r=0.538$, $\rho=0.000)$, optimism $(r=0.356, \rho=0.000)$, self-control $(r=0.306, \rho=0.002)$ and self-esteem $(r=0.279, \rho=0.005)$ respectively. The results of multiple logistic regression show that social relation has the greatest odds ratio (OR) of 16.061, meaning that good social relationships would improve subjective well-being 16 times higher than the caregivers of people with schizophrenia who did not establish good social relations with others. Social relations are the most dominant factor associated with subjective well-being of caregivers of people with schizophrenia. Caregivers of people with schizophrenia who establish good social relationships with others will experience happiness and life satisfaction, so they can improve subjective well-being.
\end{abstract}

Keywords: Caregiver, schizophrenia caregiver, subjective well-being

Korespondensi: Yhummei Veronia F. Program Studi Magister Keperawatan Fakultas Kedokteran Universitas Brawijaya Malang. Jl. Veteran Malang 65145 Tel. (0341) 551611 Email: meinurhayati16@gmail.com

DOI: http://dx.doi.org/10.21776/ub.jkb.2018.030.02.12 


\section{PENDAHULUAN}

Gangguan jiwa merupakan masalah kesehatan jiwa yang serius di dunia. Pedoman Penggolongan dan Diagnosis Gangguan Jiwa (PPDGJ) III mengklasifikasi gangguan jiwa menjadi beberapa jenis gangguan, salah satunya yaitu gangguan mental psikotik (1). Gangguan mental psikotik merupakan gangguan jiwa ketika seseorang mengalami kehilangan kemampuan menilai kenyataan. Jenis yang paling banyak dialami oleh seseorang adalah skizofrenia yang ditandai oleh penyimpangan pikiran, persepsi, emosi, mengenal diri sendiri dan perilaku $(2,3)$. Data dari Riset Kesehatan Dasar 2013 menunjukkan bahwa skizofrenia dialami oleh sekitar 400.000 orang atau 1,7 per 1.000 penduduk Indonesia (4). Disfungsi kognisi sosial merupakan gangguan pada skizofrenia yang dapat mempengaruhi fungsi sosial sehingga hubungan sosial terganggu dan menghindari kontak dengan lingkungan (57). Gangguan tersebut membuat orang dengan skizofrenia memerlukan dukungan dan bantuan dalam memenuhi kebutuhan sehari-hari pada orang lain atau caregiver. Orang dengan skizofrenia yang dirawat di rumah dapat menjadi beban bagi keluarga terutama caregiver. Caregiver dalam merawat orang dengan skizofrenia memiliki berbagai permasalahan seperti kesulitan dalam menghadapi dan menangani perilaku yang ditimbulkan oleh gejala negatif orang dengan skizofrenia, stigma masyarakat terhadap orang dengan skizofrenia dan kesulitan menjalin hubungan sosial dengan masyarakat (8). Beban pengasuhan orang dengan skizofrenia tersebut menjadi stresor bagi caregiver dan sebanyak $89 \%$ caregiver merasa terbebani oleh kondisi orang dengan skizofrenia (9).

Caregiver yang merawat orang dengan skizofrenia mengalami stres ringan sebanyak $14,7 \%$ dan merasa pasrah dalam merawat anggota keluarga yang menderita skizofrenia sebab sudah tidak dapat mengupayakan kesembuhan sehingga memasrahkan perawatan orang dengan skizofrenia pada orang lain selain keluarga yang bersedia membantu $(10,11)$. Caregiver yang merawat orang dengan skizofrenia juga merasa sedih, kesal akibat perlakuan negatif orang dengan skizofrenia, selalu memikirkan masa depan dan keselamatan orang dengan skizofrenia serta merasa lelah sepanjang waktu (11). Caregiver selama merawat orang dengan skizofrenia juga susah tidur di malam hari dan tidak memiliki finansial yang cukup untuk mengobati anggota keluarga dengan skizofrenia karena tidak bekerja. Pengasuhan orang dengan skizofrenia membuat emosi dan perasaan caregiver berubah-ubah yang dapat meningkatkan beban pengasuhan dan kesejahteraan subjektif rendah (11). Isnaeni (2015) mengemukakan bahwa hal yang membuat kebahagiaan caregiver orang dengan skizofrenia yaitu perilaku adaptif dan kestabilan emosi orang dengan skizofrenia (12). Penelitian tersebut menyatakan bahwa caregiver kurang merasakan kebahagiaan karena perilaku maladaptif, emosi yang tidak stabil dan kekambuhan orang dengan skizofrenia (12). Hasil penelitian yang dilakukan oleh Subu et al., menunjukkan bahwa keluarga yang merawat orang dengan skizofrenia merasa takut jika orang dengan gangguan jiwa tersebut akan mengulangi perilaku kekerasan yang menyebabkan keluarga tidak nyaman jika orang dengan gangguan jiwa berada di rumah (13).

Jumlah orang dengan skizofrenia di wilayah Kerja Puskesmas Bantur Kabupaten Malang pada tahun 2017 adalah 134 orang. Hasil wawancara yang telah dilakukan pada beberapa caregiver yang merawat orang dengan skizofrenia di wilayah kerja Puskesmas Bantur menunjukkan bahwa caregiver merasa lelah dan kurang tidur selama merawat orang dengan skizofrenia sebab harus memasak, mencuci baju, bekerja, mengurus anggota keluarga yang lain dan melakukan kegiatan lainnya. Caregiver yang merawat orang dengan skizofrenia tersebut mengungkapkan bahwa sering marah-marah dan terkadang hampir ingin memukul orang dengan skizofrenia sebab tidak dapat mengatasi perlakuan negatif orang dengan skizofrenia tersebut. Berdasarkan latar belakang permasalahan yang telah diuraikan di atas bahwa kesejahteraan subjektif memiliki peranan penting bagi caregiver dalam melakukan peran perawatan dan pengasuhan terutama pada caregiver yang merawat orang dengan skizofrenia. Oleh karena itu dilakukan penelitian yang bertujuan untuk mengetahui tingkat kesejahteraan subjektif serta faktor-faktor yang berhubungan dengan kesejahteraan subjektif pada caregiver yang merawat orang dengan skizofrenia.

\section{METODE}

Penelitian ini merupakan penelitian observasional dengan pendekatan cross-sectional. Penelitian ini telah mendapatkan kelaikan etik dari Komisi Etik Penelitian Kesehatan Fakultas Kedokteran Universitas Brawijaya No. 06/EC/KEPK-S2/01/2018. Penelitian dilakukan di lima desa yaitu Desa Bandungrejo, Bantur, Sumberbening, Srigonco dan Wonorejo yang berada dalam wilayah kerja Puskesmas Bantur Kecamatan Bantur Kabupaten Malang. Penelitian dilakukan pada bulan Februari hingga Maret 2018.

\section{Subjek Penelitian}

Populasi pada penelitian ini adalah caregiver sejumlah orang dengan skizofrenia yaitu 134 orang. Responden pada penelitian ini diperoleh dengan menggunakan purposive sampling sebanyak 102 orang caregiver yang merawat orang dengan skizofrenia selama 24 jam dan telah merawat orang dengan skizofrenia lebih dari 10 tahun serta caregiver orang dengan skizofrenia yang bersedia menjadi responden pada penelitian ini. Subyek penelitian telah memenuhi kriteria inklusi pada penelitian ini yaitu caregiver informal yang berasal dari keluarga inti orang dengan skizofrenia yang merawat orang dengan skizofrenia di rumah selama 24 jam dan telah merawat lebih dari 5 tahun. Kriteria eksklusi pada penelitian ini yaitu responden yang tidak bersedia atau menolak untuk berpartisipasi pada penelitian ini.

\section{Alat Pengumpulan Data}

Pengumpulan data dilakukan dengan menggunakan lima alat ukur berupa kuesioner yaitu Rosenberg's Self-Esteem Scale untuk mengukur variabel harga diri yang telah mendapatkan ijinan dari Dr. Florence Rosenberg untuk menggunakan kuesioner ini yang terdiri dari 10 butir pernyataan, self-control scale untuk mengukur variabel kontrol diri yang terdiri dari 7 butir pernyataan, optimism scale untuk mengukur variabel sikap optimis yang terdiri dari 8 butir pernyataan, social connectedness scale untuk mengukur variabel hubungan sosial yang terdiri dari 5 butir pernyataan dan The Satisfaction with Life Scale untuk mengukur variabel kesejahteraan subjektif yang terdiri dari 5 butir pernyataan. Alat ukur tersebut dimodifikasi oleh peneliti dengan diterjemahkan ke dalam Bahasa Indonesia dan telah dilakukan uji validitas dan reliabilitas. 


\section{Uji Validitas dan Reliabilitas}

Uji validitas pada kelima alat ukur tersebut dilakukan dengan korelasi bivariat Pearson pada program PASW (Predictive Analytics SoftWare) Statistics 18. Hasil uji validitas menunjukkan bahwa seluruh item pernyataan pada kelima alat ukur tersebut dinyatakan valid dengan nilai Pearson Correlation lebih besar dari nilai $r$ tabel yaitu 0,444 untuk $\mathrm{N}=20$ pada taraf signifikansi $5 \%$. Uji reliabilitas pada kelima alat ukur tersebut dilakukan dengan uji statistik Cronbach Alpha pada program PASW (Predictive Analytics SoftWare) Statistics 18 dengan ketentuan nilai Cronbach Alpha $>0,6$. Hasil uji reliabilitas menunjukkan bahwa seluruh item pernyataan pada kelima alat ukur tersebut dinyatakan reliabel.

\section{Analisis Data}

Penelitian ini menggunakan uji korelasi Rank Spearman untuk menganalisis masing-masing faktor yang berhubungan dengan kesejahteraan subjektif. Analisis data multivariat dilakukan dengan menggunakan regresi logistik berganda untuk mengetahui variabel yang paling dominan berhubungan dengan kesejahteraan subjektif pada caregiver yang merawat orang dengan skizofrenia.

\section{HASIL}

\section{Data Demografi Responden Penelitian}

Distribusi frekuensi karakteristik responden penelitian meliputi usia, jenis kelamin, pendidikan, pekerjaan, hubungan keluarga dan lama merawat orang dengan skizofrenia dapat dilihat pada Tabel 1.

Tabel 1. Karakteristik responden penelitian berdasarkan usia, jenis kelamin, pendidikan, pekerjaan, hubungan keluarga dan lama merawat orang dengan skizofrenia

\begin{tabular}{|c|c|c|}
\hline Karakteristik Responden & Frekuensi (N) & Persentase (\%) \\
\hline \multicolumn{3}{|l|}{ Usia } \\
\hline 30-40 tahun & 12 & 11,76 \\
\hline 41-51 tahun & 37 & 36,27 \\
\hline 52-62 tahun & 42 & 41,18 \\
\hline $63-73$ tahun & 11 & 10,78 \\
\hline Total & 102 & 100 \\
\hline \multicolumn{3}{|l|}{ Jenis Kelamin } \\
\hline Laki-laki & 45 & 44,12 \\
\hline Perempuan & 57 & 55,88 \\
\hline Total & 102 & 100 \\
\hline \multicolumn{3}{|l|}{ Pendidikan } \\
\hline Tidak sekolah & 22 & 21,57 \\
\hline SD & 68 & 66,67 \\
\hline SMP & 11 & 10,78 \\
\hline SMA & 1 & 0,98 \\
\hline Total & 102 & 100 \\
\hline \multicolumn{3}{|l|}{ Pekerjaan } \\
\hline Petani & 49 & 48,04 \\
\hline Wiraswasta & 18 & 17,65 \\
\hline Ibu rumah tangga & 35 & 34,31 \\
\hline Total & 102 & 100 \\
\hline \multicolumn{3}{|l|}{ Hubungan Keluarga } \\
\hline Orang tua kandung & 32 & 31,37 \\
\hline Anak kandung & 25 & 24,51 \\
\hline Istri/ suami & 28 & 27,45 \\
\hline Kakak/ adik kandung & 17 & 16,67 \\
\hline Total & 102 & 100 \\
\hline \multicolumn{3}{|c|}{ Lama Merawat Orang dengan Skizofrenia } \\
\hline 10-15 tahun & 44 & 43,14 \\
\hline 16-21 tahun & 32 & 31,37 \\
\hline 22-27 tahun & 26 & 25,49 \\
\hline Total & 102 & 100 \\
\hline
\end{tabular}

Responden terbanyak berusia antara 52-62 tahun sebanyak 42 orang $(41,18 \%)$, jumlah responden perempuan lebih banyak daripada laki-laki sebanyak 57 orang $(55,88 \%)$, tingkat pendidikan terbanyak yaitu SD sebanyak 68 orang $(66,67 \%)$, bekerja sebagai petani sebanyak 49 orang $(48,04 \%)$, hubungan keluarga antara responden sebagai caregiver dengan orang dengan skizofrenia sebagai orang tua kandung sebanyak 32 orang $(31,37 \%)$, waktu lama merawat selama $10-15$ tahun sebanyak 44 orang $(43,14 \%)$. Sebagian besar responden pada penelitian ini adalah orang tua kandung dengan usia pertengahan (paruh baya) yang merawat anaknya yang menderita skizofrenia dalam waktu lebih dari 10 tahun dimulai sejak orang dengan skizofrenia tersebut berusia remaja hingga dewasa.

\section{Karakteristik Responden Penelitian}

Karakteristik responden penelitian dijabarkan berdasarkan variabel penelitian yaitu harga diri, kontrol diri, sikap optimis, hubungan sosial dan kesejahteraan subjektif (Tabel 2)

Responden pada penelitian ini sebagian besar memiliki harga diri sedang (66 orang, 64,71\%), kontrol diri sedang (65 orang, 63,73\%), dan sikap kurang optimis sebanyak 68 orang $(66,67 \%)$. Sebagian besar responden mempunyai hubungan sosial sedang (52 orang, 50,98\%) dan kesejahteraan subjektif sedang (69 orang, 67,65\%).

Tabel 2. Karakteristik responden penelitian berdasarkan variabel penelitian

\begin{tabular}{lrr}
\hline \multicolumn{1}{c}{ Variabel } & Frekuensi (N) & Persentase (\%) \\
\hline Harga Diri & & \\
Harga diri tinggi & 36 & 35,29 \\
Harga diri sedang & 66 & 64,71 \\
$\quad$ Total & 102 & 100 \\
Kontrol Diri & & \\
$\quad$ Kontrol diri tinggi & 37 & 36,27 \\
Kontrol diri sedang & 65 & 63,73 \\
$\quad$ Total & 102 & 100 \\
Sikap Optimis & & \\
$\quad$ Optimis & 34 & 33,33 \\
$\quad$ Kurang optimis & 68 & 66,67 \\
$\quad$ Total & 102 & 100 \\
Hubungan Sosial & & \\
Hubungan sosial tinggi & 50 & 49,02 \\
$\quad$ Hubungan sosial sedang & 52 & 100 \\
Total & 102 & \\
Kesejahteraan Subjektif & & 32,35 \\
Kesejahteraan subjektif tinggi & 33 & 67,65 \\
Kesejahteraan subjektif sedang & 69 & 100 \\
$\quad$ Total & 102 & \\
\hline
\end{tabular}

Hubungan Harga Diri, Kontrol Diri, Sikap Optimis, dan Hubungan Sosial dengan Kesejahteraan Subjektif

Hasil analisis bivariat antara harga diri, kontrol diri, sikap optimis dan hubungan sosial kesejahteraan subjektif pada caregiver dengan skizofrenia disajikan pada Tabel 3. Hasil menunjukkan bahwa variabel yang berhubungan signifikan dengan kesejahteraan subjektif secara berturut-turut yaitu hubungan sosial $(r=0,538, \rho=0,000)$, sikap optimis $(r=0,356$, $\rho=0,000)$, kontrol diri $(r=0,306, \rho=0,002)$ dan harga diri $(r=0.279, \rho=0,005)$. Nilai koefisien korelasi sikap optimis, kontrol diri dan harga diri dengan kesejahteraan subjektif menunjukkan kekuatan hubungan lemah dan nilai koefisien 
Tabel 3. Hubungan harga diri, kontrol diri, sikap optimis dan hubungan sosial dengan kesejahteraan subjektif pada caregiver orang dengan skizofrenia

\begin{tabular}{|c|c|c|c|c|c|c|c|c|c|}
\hline & & \multicolumn{6}{|c|}{ Kesejahteraan Subjektif } & \multirow{3}{*}{$\begin{array}{l}\text { Koefisien } \\
\text { Korelasi (r) }\end{array}$} & \multirow{3}{*}{ Nilai $\rho$} \\
\hline \multicolumn{2}{|c|}{ Variabel } & \multicolumn{2}{|c|}{ Tinggi } & \multicolumn{2}{|c|}{ Sedang } & \multicolumn{2}{|c|}{ Total } & & \\
\hline & & $\mathbf{N}$ & $\%$ & $\mathbf{N}$ & $\%$ & $\mathbf{N}$ & $\%$ & & \\
\hline \multirow[t]{2}{*}{ Harga Diri } & Tinggi & 18 & 54,55 & 18 & 26,09 & 36 & 35,29 & 0,279 & 0,005 \\
\hline & Sedang & 15 & 45,45 & 51 & 73,91 & 66 & 64,71 & & \\
\hline Kontrol Diri & Total & 33 & 100 & 69 & 100 & 102 & 100 & & \\
\hline \multirow[t]{2}{*}{ Sikap Optimis } & Tinggi & 19 & 57,58 & 18 & 26,09 & 37 & 36,27 & 0,306 & 0,002 \\
\hline & Sedang & 14 & 42,42 & 51 & 73,91 & 65 & 63,73 & & \\
\hline \multirow{8}{*}{$\begin{array}{l}\text { Hubungan } \\
\text { Sosial }\end{array}$} & Total & 33 & 100 & 69 & 100 & 102 & 100 & & \\
\hline & Optimis & 19 & 57,58 & 15 & 21,74 & 34 & 33,33 & 0,356 & 0,000 \\
\hline & Kurang & 14 & 42,42 & 54 & 78,26 & 68 & 66,67 & & \\
\hline & Optimis & & & & & & & & \\
\hline & Total & 33 & 100 & 69 & 100 & 102 & 100 & & \\
\hline & Tinggi & 29 & 87,88 & 21 & 30,43 & 50 & 49,02 & 0,538 & 0,000 \\
\hline & Sedang & 4 & 12,12 & 48 & 69,57 & 52 & 50,98 & & \\
\hline & Total & 33 & 100 & 69 & 100 & 102 & 100 & & \\
\hline
\end{tabular}

korelasi hubungan sosial dengan kesejahteraan subjektif menunjukkan kekuatan hubungan sedang. Arah hubungan semua variabel tersebut positif yang berarti semakin baik hubungan sosial, sikap optimis, kontrol diri dan harga diri maka semakin baik pula kesejahteraan subjektif pada caregiver yang merawat orang dengan skizofrenia.

\section{Faktor Dominan yang Berhubungan dengan Kesejahteraan Subjektif}

Hasil uji regresi logistik berganda dapat dilihat pada Tabel 4. Hasil regresi logistik berganda menunjukkan bahwa sikap optimis (adjusted OR=6,821, $\rho=0,002$ ) dan hubungan sosial (adjusted OR=16,061, $\rho=0,000$ ) berhubungan secara bermakna dengan kesejahteraan subjektif. Nilai Odds Ratio tersebut didapat setelah variabel harga diri dan kontrol diri yang merupakan variabel perancu dikontrol. Variabel yang paling besar pengaruhnya terhadap kesejahteraan subjektif pada caregiver yang merawat orang dengan skizofrenia di wilayah kerja Puskesmas Bantur Kabupaten Malang adalah hubungan sosial. Hubungan sosial memiliki odds ratio (OR) paling besar yaitu 16,061 artinya hubungan sosial yang baik dengan orang lain akan meningkatkan kesejahteraan subjektif 16 kali lebih tinggi dibandingkan dengan caregiver orang dengan skizofrenia yang tidak menjalin hubungan sosial yang baik dengan orang lain setelah dikontrol oleh variabel sikap optimis, harga diri dan kontrol diri. Nilai Nagelkerke $R$ Square sebesar 0,531 yang menunjukkan bahwa kemampuan variabel harga diri, kontrol diri, sikap optimis dan hubungan sosial dalam menjelaskan kesejahteraan subjektif adalah sebesar $53,1 \%$ dan terdapat $46,9 \%$ faktor lain di luar model yang menjelaskan kesejahteraan subjektif.

Tabel 4. Hasil uji regresi logistik berganda

\begin{tabular}{|c|c|c|c|c|c|}
\hline \multirow{2}{*}{ Variabel } & \multirow{2}{*}{ Nilai $\rho$} & \multirow{2}{*}{$\begin{array}{c}\text { Adjusted } \\
\text { Odds Ratio }\end{array}$} & \multicolumn{2}{|c|}{$\begin{array}{c}95 \% \text { Confidence } \\
\text { Interval }\end{array}$} & \multirow{2}{*}{$\begin{array}{l}\text { Nagelkerke } \\
\text { R Square }\end{array}$} \\
\hline & & & $\begin{array}{l}\text { Lower } \\
\text { Bound }\end{array}$ & $\begin{array}{l}\text { Upper } \\
\text { Bound }\end{array}$ & \\
\hline Harga diri & 0,133 & 2,522 & 0,753 & 8,444 & \multirow{2}{*}{0,531} \\
\hline Kontrol diri & 0,248 & 2,017 & 0,813 & 6,639 & \\
\hline
\end{tabular}

Tabel 4. Hasil uji regresi logistik berganda (Lanjutan)

\begin{tabular}{|c|c|c|c|c|c|}
\hline \multirow{2}{*}{ Variabel } & \multirow{2}{*}{ Nilai $\rho$} & \multirow{2}{*}{$\begin{array}{c}\text { Adjusted } \\
\text { Odds Ratio }\end{array}$} & \multicolumn{2}{|c|}{$\begin{array}{c}\text { 95\% Confidence } \\
\text { Interval }\end{array}$} & \multirow{2}{*}{$\begin{array}{l}\text { Nagelkerke } \\
\text { RSquare }\end{array}$} \\
\hline & & & $\begin{array}{l}\text { Lower } \\
\text { Bound }\end{array}$ & $\begin{array}{l}\text { Upper } \\
\text { Bound }\end{array}$ & \\
\hline Sikap optimis & 0,002 & 6,821 & 1,988 & 23,399 & \multirow{2}{*}{0,531} \\
\hline Hubungan sosial & 0,000 & 16,061 & 4,373 & 58,988 & \\
\hline
\end{tabular}

\section{DISKUSI}

Hubungan antara harga diri, kontrol diri, sikap optimistik dan hubungan sosial berpengaruh terhadap kesejahteraan subjektif caregivers orang dengan skizofrenia. Hubungan antara harga diri dengan kesejahteraan subjektif pada caregiver yang merawat orang dengan skizofrenia adalah positif namun lemah. Kesejahteraan subjektif berkaitan dengan kebahagiaan dan perasaan positif seseorang sebagai evaluasi kognitif dan afektif terhadap kehidupan (14). Penelitian yang dilakukan oleh Du et al., menunjukkan bahwa seseorang yang memiliki harga diri tinggi dan mempertahankannya dengan menjalin hubungan sosial dengan orang lain dapat meningkatkan kesejahteraan hidup dari waktu ke waktu (15). Penelitian lain yang dilakukan oleh Barnum dan Perrone-McGovern et al., menunjukkan bahwa anak-anak yang pernah mengalami kekerasan seksual dan memiliki trauma kekerasan seksual rendah dan harga diri tinggi akan meningkatkan kesejahteraan subjektif begitu juga sebaliknya (16). Hal tersebut sejalan dengan penelitian yang dilakukan pada caregiver yang merawat orang dengan skizofrenia di wilayah kerja Puskesmas Bantur Kabupaten Malang. Harga diri tinggi yang dimilliki oleh caregiver selama merawat orang dengan skizofrenia membuat dirinya yakin akan kemampuan yang dimiliki khususnya dalam merawat orang dengan skizofrenia agar kondisi kejiwaan orang dengan skizofrenia dapat membaik. Harga diri yang dimiliki caregiver tersebut membuat caregiver selalu merasakan sesuatu yang positif sehingga dapat merasakan kebahagiaan walaupun memiliki beban yang berat dalam merawat orang dengan 
skizofrenia.

Hubungan antara kontrol diri dengan kesejahteraan subjektif memiliki hubungan bermakna dengan nilai $\rho$ yaitu 0,002 dan nilai koefisien korelasi yaitu 0,306. Hubungan antara kontrol diri dengan kesejahteraan subjektif pada caregiver yang merawat orang dengan skizofrenia adalah positif namun lemah. Pompeo et al., menunjukkan bahwa orang tua yang memiliki anak dengan skizofrenia dapat mengontrol diri sebagai mekanisme koping adaptif untuk mengatasi masalah sehingga dapat mengurangi stres dan beban pengasuhan berkurang (17). Kontrol diri mengacu pada upaya yang dilakukan seseorang untuk mengendalikan perasaan atau tindakannya dalam menghadapi stres sehingga dapat menyadari dan memahami emosi dan dapat mengelola perilakunya (17).

Caregiver yang memiliki kontrol diri yang baik dapat melakukan sesuatu yang baik dan dapat menghindari sesuatu yang tidak baik yang dapat merugikan diri sendiri. Caregiver yang merawat orang dengan skizofrenia di wilayah kerja Puskesmas Bantur pada penelitian ini sebagian besar disiplin terhadap diri sendiri $(88,82 \%)$. Hal tersebut sesuai dengan penelitian yang dilakukan oleh Ronen et al., yang mengemukakan bahwa keterampilan kontrol diri yang baik pada remaja yang mengalami krisis diri dapat memberikan pengaruh positif pada dirinya (18). Caregiver orang dengan skizofrenia di wilayah kerja Puskesmas Bantur pada penelitian ini sebanyak $82,87 \%$ memiliki kontrol diri yang baik sehingga dengan mudah dapat menghindari kebiasaan yang tidak baik. Kontrol diri mempengaruhi kesejahteraan subjektif secara positif dan seseorang yang memiliki kontrol diri yang tinggi akan memiliki kesehatan yang baik (19). Kontrol diri yang tinggi membuat caregiver tidak mudah emosi dalam menghadapi perlakuan negatif yang ditimbulkan oleh orang dengan skizofrenia sehingga dapat terus merawat orang dengan skizofrenia agar kondisi kejiwaannya membaik.

Hubungan antara sikap optimis dengan kesejahteraan subjektif pada caregiver yang merawat orang dengan skizofrenia adalah positif namun lemah. Caregiver orang dengan skizofrenia di wilayah kerja Puskesmas Bantur pada penelitian ini sebanyak $90,36 \%$ optimis karena dapat merawat orang dengan skizofrenia. Caregiver tersebut tetap meyakini sesuatu yang baik dan memiliki harapan baik dalam berbagai hal khususnya dalam merawat orang dengan skizofrenia. Oliveira et al., mengemukakan bahwa orang lanjut usia sebagai caregiver informal yang juga merawat orang lanjut usia yang memiliki optimisme tinggi memiliki tingkat stres rendah (20). Pengasuhan pada orang yang telah lanjut usia juga merupakan hal yang berat bagi caregiver yang dapat mempengaruhi emosi, kecemasan hingga depresi.

Sikap optimis dapat menghasilkan sesuatu yang baik saat menghadapi hal yang sulit seperti melakukan peran pengasuhan dimana optimisme yang tinggi akan meningkatkan kesejahteraan subjektif menjadi lebih baik (21). Sikap pesimis dapat memberikan hasil yang tidak baik dan menghasilkan lebih banyak perasaan negatif seperti kegelisahan, kemarahan, kesedihan bahkan keputusasaan (21). Caregiver orang dengan skizofrenia di wilayah kerja Puskesmas Bantur pada penelitian ini sebanyak $87,12 \%$ optimis tentang masa depan khususnya tentang peningkatan kondisi kesehatan jiwa orang dengan skizofrenia. Conversano et al. mengemukakan bahwa sikap optimis dapat mempengaruhi kesehatan fisik dan mental serta dapat menghadapi kehidupan sosial dan kegiatan sehari-hari dengan baik (22). Penelitian tersebut juga menyatakan bahwa seseorang yang optimis lebih berhasil dalam menghadapi keadaan yang tidak menyenangkan dibandingkan dengan seseorang yang pesimis. Caregiver yang memiliki sikap optimis mampu merawat orang dengan skizofrenia dengan baik sehingga memiliki kesejahteraan subjektif yang baik pula.

Hubungan antara hubungan sosial dengan kesejahteraan subjektif pada caregiver yang merawat orang dengan skizofrenia adalah positif dan memiliki kekuatan hubungan sedang. Caregiver orang dengan skizofrenia di wilayah kerja Puskesmas Bantur pada penelitian ini sebanyak $88,68 \%$ tetap menjalin hubungan sosial dengan orang lain walaupun memiliki beban dalam merawat dan mengasuh orang dengan skizofrenia. Hasil penelitian yang dilakukan oleh Ozturk et al., menunjukkan bahwa kesejahteraan subjektif secara positif berkaitan erat dengan hubungan sosial dan berhubungan negatif dengan komponen yang memiliki hubungan dengan kesepian seperti kepuasan dengan persahabatan, hubungan sosial yang memuaskan, gejala depresi, kecemasan sosial dan isolasi sosial (23).

Hubungan sosial juga berkaitan erat dengan kesehatan mental dan kesejahteraan seseorang (24). Hasil penelitian yang dilakukan oleh Siedlecki et al., bertujuan untuk mengetahui hubungan sosial dengan kesejahteraan subjektif pada usia muda dan tua menunjukkan bahwa seseorang yang berusia muda yang mendapatkan dukungan sosial memiliki kesejahteraan subjektif yang lebih baik daripada seseorang yang berusia lanjut (25). Seseorang yang berusia muda pada penelitian tersebut mendapatkan dukungan sosial sebab menjalin hubungan sosial yang baik dengan orang lain. Dukungan sosial yang didapatkan oleh seseorang tersebut dapat mempengaruhi kepuasan hidup untuk memperbaiki kondisi kehidupan jika diperlukan. Hasil penelitian tersebut menunjukkan bahwa dukungan sosial yang diberikan berbeda-beda dalam meningkatkan kesejahteraan subjektif pada seseorang. Orang dengan skizofrenia tidak membuat caregiver mengucilkan diri dari lingkungan sosial. Orang lain juga tidak mengucilkan caregiver beserta keluarganya termasuk orang dengan skizofrenia. Orang lain memberikan dukungan sosial yang baik berupa materi maupun moril yang membuat caregiver merasa senang. Hal tersebut membuat caregiver tetap menjalin hubungan sosial dengan orang lain dan dapat meningkatkan kesejahteraan subjektif.

Pengasuhan dan perawatan orang dengan skizofrenia menjadi beban bagi caregiver yang dapat mempengaruhi kesejahteraan subjektif caregiver orang dengan skizofrenia. Caregiver orang dengan skizofrenia dapat mengelola emosi dengan baik sehingga dapat mengontrol dirinya untuk menghadapi perilaku kekerasan orang dengan skizofrenia dan optimis mampu merawat orang dengan skizofrenia agar kondisi kesehatan jiwa orang dengan skizofrenia dapat membaik. Harga diri tinggi yang dimiliki orang dengan skizofrenia juga mempengaruhi caregiver untuk tetap merawat orang dengan skizofrenia dengan baik. Caregiver orang dengan skizofrenia juga tetap menjalin hubungan sosial yang baik dengan orang lain sehingga tetap merasakan kebahagiaan dan meningkatkan kesejahteraan subjektif. Faktor-faktor yang berhubungan dengan kesejahteraan subjektif pada caregiver orang dengan skizofrenia adalah: (1) harga diri; (2) kontrol diri; (3) sikap optimis; (4) hubungan sosial. Hubungan sosial merupakan 
faktor yang paling dominan berhubungan dengan kesejahteraan subjektif pada caregiver yang merawat orang dengan skizofrenia. Hubungan sosial tinggi yang

\section{DAFTAR PUSTAKA}

1. Maslim R. Buku Saku Diagnosis Gangguan Jiwa, Rujukan Ringkas PPDGJ-III dan DSM-V. Jakarta: Nur Jaya; 2013; p. 4.

2. Gaebel W and Zielasek J. Focus on Psychosis. Dialogues in Clinical Neuroscience. 2015: 17(1): 9-18.

3. World Health Organization. Schizophrenia. (Online) 2018. http://www.who.int/en/news-room/factsheets/detail/schizophrenia. [diakses tanggal 18 April 2018].

4. Departemen Kesehatan Republik Indonesia. Riset Kesehatan Dasar 2013. Jakarta: Badan Penelitian dan Pengembangan Kesehatan Departemen Kesehatan Republik Indonesia; 2013.

5. Green MF. Impact of Cognitive and Social Cognitive Impairment on Functional Outcomes in Patients with Schizophrenia. The Journal of Clinical Psychiatry. 2016; 77(2): 8-11.

6. Green MF, Horan WP, and Lee J. Social Cognition in Schizophrenia. Nature Reviews Neuroscience. 2015; 16(10): 620-631.

7. Pinkham AE. Social Cognition in Schizophrenia. The Journal of Clinical Psychiatry. 2014; 75(2): 14-19.

8. Yusuf AJ, Nuhu FT, and Akinbiyi A. Caregiver Burden among Relatives of Patients with Schizophrenia in Katsina Nigeria. South African Journal of Psychiatry. 2009; 15(2): 43-47.

9. Fitrikasari A, Kadarman AS, Woroasih S, dan Sarjana WAS. Gambaran Beban Caregiver Orang dengan Skizofrenia di Poliklinik Rawat Jalan RSJ Amino Gondohutomo Semarang. Medica Hospitalia. 2012; 1 (2): 118-122.

10. Mirza, Raihan, dan Kurniawan H. Hubungan Lamanya Perawatan Pasien Skizofrenia dengan Stres Keluarga. Jurnal Kedokteran Syiah Kuala. 2016; 15(3): 179-189.

11. Wardhani RSP. Penerimaan Keluarga Terhadap Pasien Skizofrenia yang Menjalani Rawat Inap di Rumah Sakit Jiwa Daerah Surakarta. [Skripsi]. Universitas Muhammadiyah Surakarta, Surakarta. 2013.

12. Isnaeni T. Kebahagiaan pada Informal Caregiver Orang dengan Skizofrenia. [Skripsi]. Universitas Negeri Semarang, Semarang. 2015.

13. Subu MA, Waluyo I, Nurdin AE, Priscilla V, dan Aprina T. Stigma, Stigmatisasi, Pola Kekerasan dan Ketakutan dari Orang dengan Gangguan Jiwa (ODGJ) di Indonesia: Penelitian Constructivist Grounded Theory. Jurnal Kedokteran Brawijaya. dijalin oleh caregiver dengan orang lain akan membuat caregiver orang dengan skizofrenia merasakan kebahagiaan dan meningkatkan kesejahteraan subjektif.

2018; 30(1): 53-60.

14. Gulacti, F. The Effect of Perceived Social Support on Subjective Well-Being. Procedia Social and Behavioral Sciences. 2010; 2(2): 3844-3849.

15. Du H, King RB, and Chi P. Self-Esteem and Subjective Well-Being Revisited: The Role of Personal, Relational, and Collective Self-Esteem. PLoS One. 2017; 12(8): 1-17.

16. Barnum EL and Perrone-McGovern KM. Attachment, Self-Esteem and Subjective Well-Being among Survivors of Childhood Sexual Trauma. Journal of Mental Health Counseling. 2017; 39(1): 39-55.

17. Pompeo DA, Carvalho AD, Olive AM, Souza MGG, and Galera SAF. Strategies for Coping with Family Members of Patients with Mental Disorders. Revista Latino-Americana de Enfermagem. 2016; 24: 1-8.

18. Ronen T, Hamama L, Rosenbaum M, and MishelyYarlap A. Subjective Well-Being in Adolescence: The Role of Self-Control, Social Support, Age, Gender, and Familial Crisis. Journal of Happiness Studies. 2014; 17(1): 81-104.

19. Moffitt TE, Arseneault L, Belsky D, et al. A Gradient of Childhood Self-Control Predicts Health, Wealth, and Public Safety. Proceedings of the National Academy of Sciences of the United States of America. 2011; 108(7): 2693-2698.

20. Oliveira NA, Souza EN, Luchesi BM, Inouye K, and Pavarini SCI. Stress and Optimism of Elderlies who are Caregivers for Elderlies and Live with Children. Revista Brasileira de Enfermagem. 2017; 70(4):697-703.

21. Carver SC, Scheier MF, and Segerstrom SC. Optimism. Clinical Psychology Review. 2010; 30(7): 879-889.

22. Conversano C, Rotondo A, Lensi E, Vista OD, Arpone $\mathrm{F}$, and Reda MA. Optimism and Its Impact on Mental and Physical Well-Being. Clinical Practice Epidemiology in Mental Health. 2010; 6(1): 25-29.

23. Ozturk A and Mutlu T. The Relationship between Attachment Style, Subjective Well-Being, Happiness and Social Anxiety among University Students'. Procedia Social and Behavioral Sciences. 2010; 9: 1772-1776.

24. McLaren S and Challis C. Resilience among Men Farmers: The Protective Roles of Social Support and Sense of belonging in The Depression-Suicidal Ideation Relation. Death Studies. 2009; 33(3): 262-276.

25. Siedlecki KL, Salthouse TA, Oishi S, and Jeswani S. The Relationship between Social Support and Subjective Well-Being Across Age. Social Indicators Research. 2014; 117(2): 561-576. 